\title{
Transport of lons and Solvent Through a Nafion Membrane Modified with Polypyrrole
}

\author{
Feina $\mathrm{Xu}^{1}$, Mostèfa Kameche ${ }^{2}$ and Christophe Innocent ${ }^{1, *}$ \\ ${ }^{1}$ Institut Européen des Membranes, UMR 5635, Université Montpellier II,CC 047, Place Eugène Bataillon, \\ 34095 Montpellier cedex 5, France \\ ${ }^{2}$ Université des Sciences et de la Technologie d'Oran-Mohammed Boudiaf, Laboratoire de Physico-Chimie \\ des Matériaux, Environnement et Catalyse, Faculté des Sciences, M'Nouar BP, 1505, Oran, Algeria
}

\begin{abstract}
The Nafion ${ }^{\circledR} 117$ membrane was modified chemically, using a conducting polymer pyrrole. The oxidants ferric chloride (PPy-Fe), hydrogen peroxide (PPy-O) and ammonium persulfate (PPy-S) were used to carry out the polymerization in the membrane both in aqueous and organic media. The Nafion ${ }^{\circledR}$ modified in the presence of the $\mathrm{N}$ méthylformamide increases the transport of alkali and heavy metal cations and reduces considerably the transport of methanol both in diffusion and electro-osmosis. Therefore, the modified Nafion ${ }^{\circledR}$ membrane can be used successfully in electrodialysis of electrolyte solutions in both aqueous and hydro-organic media and may be regarded as a good material to use in Direct Methanol Fuel Cells.
\end{abstract}

Keywords: Polymerisation, Polypyrrole, Nafion ${ }^{\circledR}$, Transport, Metal Cation, Methanol.

\section{INTRODUCTION}

Nowadays, research is focusing on Direct Methanol Fuel Cells, to produce clean energy and to preserve, as a result, the environment from pollution. The key material used in such cells, is the perfluorosulfonated Nafion ${ }^{\circledR}$ cation exchange membrane. This latter has a high ionic conductivity and a low electrical resistance. However, it displays a non negligible solvent crossover. For this reason, we modified it with the conducting polymer, the polypyrrole, in order to reduce the solvent leakage and in the same time to preserve its ionic conductivity. The physical-chemistry parameters used to characterise this membrane are the transport number, the electrical resistance, the ionic flux and the cation exchange capacity. Some others morphological parameters of the membrane related to the penetration of the solvent, are also studied (swelling, thickness and surface). The results obtained so far, showed that the polymerisation can be achieved in tetrahydrofuran (THF) without oxidant reagent. The modification of the membrane improves the proton conduction, and leads to a better selectivity towards monovalent metal cations against bivalents. The electrical resistance of the membrane depends both on the electrolyte and the equilibrating time. The solvent flux is higher in electro-osmosis than in diffusion.

\footnotetext{
${ }^{*}$ Address correspondence to this author at the Institut Européen des Membranes, UMR 5635, Université Montpellier II,CC 047, Place Eugène Bataillon, 34095 Montpellier cedex 5, France; Fax: +33 4 67149119; E-mail: Christophe.Innocent@iemm.univ-montp2.fr
}

In particular they highlighted the perfluorosulfonate ionomer/conducting polymer composite membranes because of its properties $[1,2]$. The incorporated polypyrrole particles can have a great influence on the properties of the matrix itself, due to the high specific surface of nano-sized particles. The existence of nanosized polypyrrole particles in the polar phase could make transport paths longer or increase the tortuosity [3]. In one study, the composite membranes of Nafion ${ }^{\circledR}$ and polypyrrole were prepared by the electrodeposition of polypyrrole on a Nafion ${ }^{\circledR}$-coated electrode [4]. Pickup and all [2] investigated the polymerization mechanism of pyrrole in the Nafion ${ }^{\circledR}$ matrix and the enhancement of the performance in Direct Methanol Fuel Cells (DMFC) $[5,6]$.

Recently, interest in the application of conducting polymers such as polypyrrole as specific ion selective membrane, conducting polymer and sensors has grown because of its unique properties [5-9]. Researchers are applying conducting polymers as membrane materials, taking advantage of their inherent conductivity and their reversible redox, electro-active properties. Burgmayer and Murray [9] developed the so-called "ion gate membranes", which consisted of polypyrrole (PPy) films with permselectivity controlled by application of potential. Smart ion-exchange membranes based on the polypyrrole are reported, in which selectivity should be selected varying the oxidation degree [10]. Reports are available, where polypyrrole membranes were used for the electrotransport of anions or cations [2], separation of 
copper(II) from mixtures with other cations [11], recovery of proteins, selective separation of different anions, etc. Based on the fact that PPY is a rigid polymer with weakly basic anion-exchange groups in acidic media, Sata et al. [12] used it to prepare composites with cation or anion-exchange membranes. They showed that different morphologies could be obtained, and demonstrated the application of the composites as monovalent ion permselective membranes or anti-fouling membranes. However, until now not much systematic research was performed on the development of PPy composite ion-exchange membranes, optimizations of their physicochemical and electrochemical properties as a function of polymerization time and their practical applicability for the separation of ions of same charge by electro-driven techniques. Previously, we have already published a part of this research work, but considering the energetic aspect only [13].

\section{EXPERIMENTAL SECTION}

\subsection{Materials}

The solvents Methanol, N-methylformamide (NMF) and tetrahydrofuran (THF) of purity greater than $99 \%$, were purchased from Fluka. $\mathrm{H}_{2} \mathrm{O}_{2}$ (35 wt. \%) from Aldrich, pyrrole $\left(\mathrm{C}_{4} \mathrm{NH}_{5}, 97 \%\right)$, ferric chloride $\left(\mathrm{FeCl}_{3}\right.$ 97\%) from Fluka, ammonium peroxodisulfate $\left[\left(\mathrm{NH}_{4}\right)_{2} \mathrm{~S}_{2} \mathrm{O}_{8}\right]$, hydrogen peroxide from Prolabo, sulphuric acid $\left(\mathrm{H}_{2} \mathrm{SO}_{4}\right)$, sodium nitrate $\left(\mathrm{NaNO}_{3}\right)$ and nitric acid $\left(\mathrm{HNO}_{3}\right)$ were all used as received. Water was deionised by reverse osmosis. Nafion ${ }^{\circledR} 117$ was purchased from Fluka and submitted to the treatments described below.

\subsection{Cells}

The Hittorf'cell used to measure the transport numbers of counter-ions, is described elsewhere [14].
The laboratory electrodialysis cell used to demineralise the organic solutions, has been previously described [15]. The effective area of membranes and electrodes (platinium-coated titanium sheets) was $41 \mathrm{~cm}^{2}$. This cell is a home-made manufactured with polytrifluorochloroethylene (PTFCE, Kel'f). The solution circulation was achieved using pumps (Asti-france) with a flow rate of $50 \mathrm{~L}^{-\mathrm{h}^{-1}}$. The details of the clip-cell used to measure the electrical conductance of the membrane are mentioned in reference [16].

\subsection{Nafion ${ }^{\circledR}$ Preparation}

Nafion ${ }^{\circledR}$ film was cut into pieces around $40 \mathrm{~cm}^{2}$. Prior to any modification with pyrrole, all membranes were treated by boiling in $3 \%$ aqueous hydrogen peroxide $(1 \mathrm{~h}$.) and rinsed with cold water. They were then soaked in $\mathrm{HNO}_{3}\left(10 \mathrm{~mol} . \mathrm{dm}^{-3}, 30 \mathrm{~min}\right.$. at room temperature) and were rinsed again, before heating in water up to $100{ }^{\circ} \mathrm{C}$, for $1 \mathrm{~h}$. After this cleaning stage, membrane samples were first soaked and then heated in sulphuric acid $1 \mathrm{~mol} . \mathrm{dm}^{-3}$, during $1 \mathrm{~h}$. at $100^{\circ} \mathrm{C}$, to ensure acidification of any remaining non-protonated sites. Cleaned and washed Nafion ${ }^{\circledR}$ samples were stored in 0.5 mol. $\mathrm{dm}^{-3}$ sulphuric acid and then, were immersed in water for $8 \mathrm{~h}$., at $80^{\circ} \mathrm{C}$. This has the effect of both removing any excess of sulphuric acid and swelling the Nafion ${ }^{\circledR}$ membrane, before modification with pyrrole.

\subsection{Chemical Modification Procedure}

The scheme represented by Figure 1, shows the various stages developed for modification of $\mathrm{Nafion}^{\circledR}$ by pyrrole impregnation/polymerization. The experimental procedure has been inspired by procedure previously published by Easton et al. [1]. Membranes was immersed in organic solvent ( $\mathrm{N}$ methylformamide and tetrahydrofuran) with pyrrole in solution instead of water solution of pyrrole. Each step was carried out at

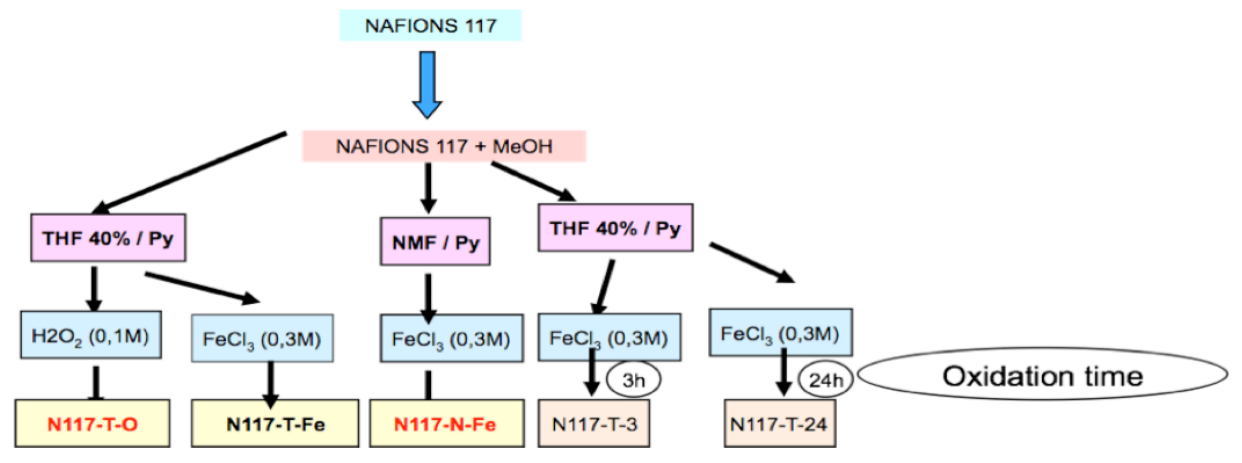

Figure 1: Chemical modification scheme. 
room temperature, for $24 \mathrm{~h}$. Modified membranes were then washed and hydrated at $80{ }^{\circ} \mathrm{C}$ for $8 \mathrm{~h}$. Nafionpyrrole membranes prepared, using ferric chloride and hydrogen peroxide oxidants are denoted N117-N-Fe, and N117-N-O respectively. Membrane modified without oxidant, only by immersion in THF are noted N117-T-X, where $X$ is the time of dipping.

\subsection{Characterisation of Modified Membrane}

The amount of polypyrrole inside the modified Nafion membranes can be considered, in a first approximation, to be the weight difference between the wet membranes before and after pyrrole modification. A more precise estimation of the amount of polypyrrole in the membrane was obtained by elementary microanalysis of carbon $(C)$, sulphur $(S)$, nitrogen $(N)$ and hydrogen $(\mathrm{H})$ (by combustion) with a Flash EA 1112 series from Thermo Finnigan. The Nafion ${ }^{\circledR}$ membrane used is a perfluorosulfonated polymer, composed only of carbon, fluorine, oxygen and sulphur. The determination of $\mathrm{S}$ and $\mathrm{N}$ contents allowed the calculation of the amount of polypyrrole inside the composite membrane system. Membrane water content was determined using a Mettler Toledo Halogen Moisture Analyser, HR73. The weight of a membrane sample $(0.1 \mathrm{~g})$, pre-conditioned as described above, was monitored with temperature up to $80^{\circ} \mathrm{C}$, where the variation of weight with time was less than 1 $\mathrm{mg} / 140 \mathrm{~s}$. The thicknesses of the membranes preconditioned as described above, were determined with an Electronic Digital Micrometer (Codiam Scientific).

The infrared spectra given by the surface of membranes was recorded using a Nicolet NEXUS Golden Gate FT-IR-ATR instrument, and the acquired data analysed with OMNIC 6.2 software.

\subsection{Ionic Transport}

The ionic transport was investigated by using two chief parameters which are the electrical resistance and the transport numbers of counter-ions. The membrane electrical resistances were deduced from conductance data, using the clip-cell mentioned above. The measurements were carried out in aqueous electrolytic solutions with a concentration equal to $0.1 \mathrm{~mol}^{-\mathrm{dm}^{-3}}$ at $25 \pm 0.1^{\circ} \mathrm{C}$. Two distinct experiments were achieved: one with the solution only and another with the membrane and the solution together. The electrolytic solutions were equilibrated in $0.1 \mathrm{~N}$ solutions during $24 \mathrm{~h}$, prior to measurements. The surface electrical resistance $R_{S}\left(\right.$ ohm.cm ${ }^{2}$ ) is related to the specific conductivity $\sigma\left(\mathrm{S} . \mathrm{cm}^{-1}\right)$ through $\sigma=\mathrm{e} / \mathrm{R}_{\mathrm{S}}$, where e $(\mathrm{cm})$ is the membrane thickness.

The transport numbers were obtained by using the Hittorf's method, on the basis of the Faraday second law. The details of experimental set up and calculations are given in [17].

\subsection{Solvent Transport}

Methanol transfer studies were conducted using the polytrifluorochloroethylene laboratory cell (PTFCE) shown in Figure 2. The study was carried out at room temperature on both modified and non-modified membrane samples of surface area $7 \mathrm{~cm}^{2}$. Contents of both cell compartments were mechanically stirred by glass-stem stirrers. The measurement of methanol flux were carried out in diffusion and in electro-osmosis modes, the latter using a current density of $10 \mathrm{~mA} . \mathrm{cm}^{-2}$. The donor compartment was filled with methanol (2 mol. $\mathrm{dm}^{-3}$ ) in $0.05 \mathrm{~mol} . \mathrm{dm}^{-3}$ sulphuric acid solution.

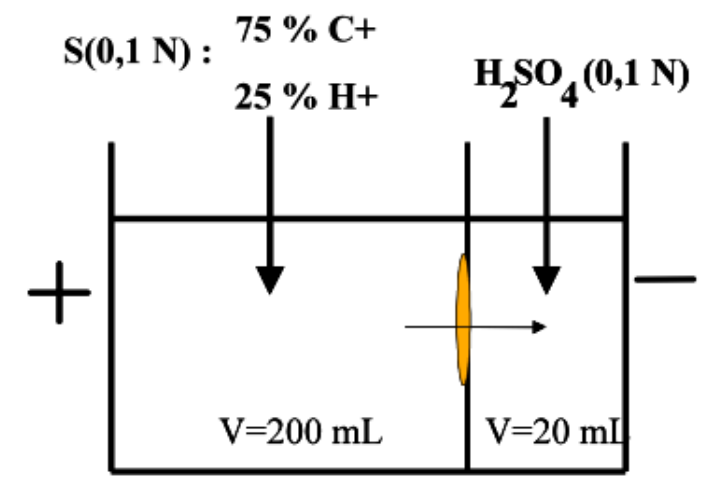

Figure 2: Hittorf's cell, S: solvent; according to ref [14] and [16].

Methanol transferred through the membrane separator was analysed by Raman spectroscopy according procedure previously reported $[19,20]$. Although not a commonly used method to quantify methanol, it allows a rapid semi-quantitative determination of methanol concentration with a $6 \%$ estimated error, and with the advantage of avoiding the salt problem that occurs using gas chromatography.

\section{RESULTS AND DISCUSSION}

\subsection{Characterisation of Modified Membrane}

\subsubsection{Influence of the Oxidant}

A preliminary study of the morphology of polypyrrole powder has been carried out to show the influence of the oxidant. Figure $\mathbf{3}$ presents the SEM picture 

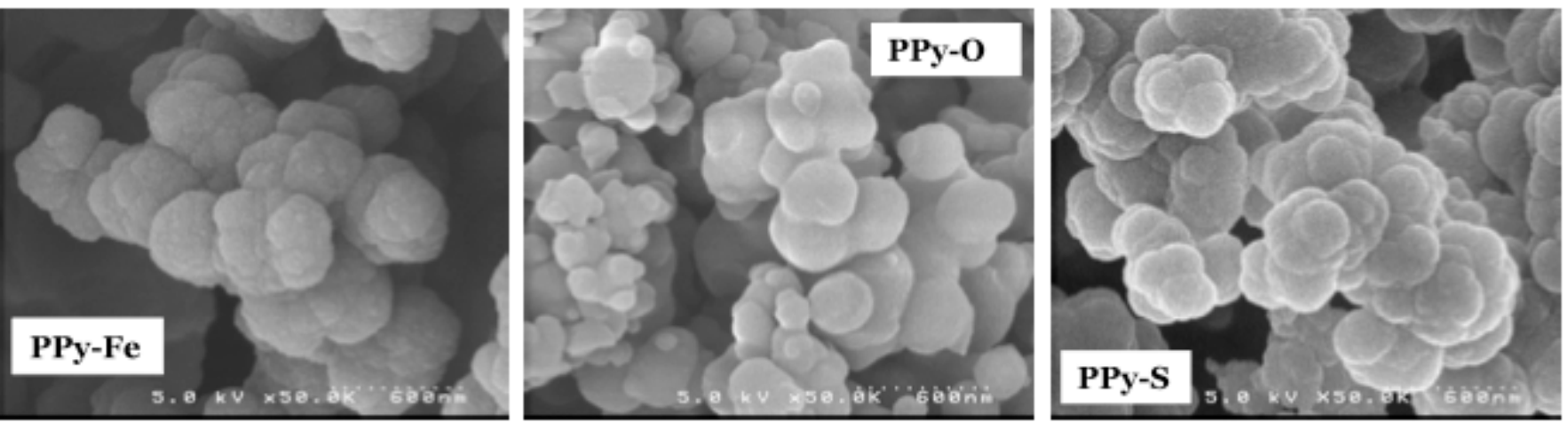

Figure 3: Polypyrrole morphologies obtained with three different oxidants: ferric chloride (PPy-Fe), hydrogen peroxide (PPy-O) and ammonium persulfate (PPy-S).

obtained with three oxidants: ferric chloride (noted PPy$\mathrm{Fe}$ ), hydrogen peroxide (PPy-O) and ammonium persulfate (PPy-S).

The structure of the beads obtained with ionic oxidants (Ferric Chloride and ammonium persulfate) seems to give the same morphology. Conversely with neutral oxidant the beads look like smoother and flatter. The interactions between monomer and reagent are not the same in presence of ionic species because the polymer (polypyrrole) is produced in the oxidized form that means in the cationic form.

\subsubsection{Modification in THF Solvent}

The characterization of the polypyrrole modified membrane has been carried out, in the first step, by weighting it and measuring both its surface and its thickness. The amount of pyrrole incorporated in the membrane has been determined owing to elementary analysis. En effect, the ratio $R=N / S$ obtained by elementary analysis, expresses the number of pyrrole units per Nafion $^{\circledR}$ ion exchange site. The measurements in different steps of modification with THF are presented in table $\mathbf{1}$. The time of modification and the influence of the pyrrole concentration have been discussed. The results are compared with the modified membrane obtained with polymerisation in THF - pyrrole solution $\left(0.7 \mathrm{~mol}_{\mathrm{d}} \mathrm{dm}^{-3}\right)$, during $24 \mathrm{~h}$.

These results show the possibility to polymerize pyrrole in the Nafion ${ }^{\circledR}$ membrane by dipping it in the THF solution without oxidant reagent. In this case, the hydration (amount of water in the membrane) has been mainly increased $(27 \%$ with hydrogen peroxide as

Table 1: Characteristics of pyrrole-modified Nafion membranes - influence of polymerization time ( $x$ : hour) and pyrrole concentration $\left(\mathrm{y}: \mathrm{mol}^{-1} \mathrm{~L}^{-1}\right): \Delta \mathrm{S}$ increase of surface membrane; $\Delta \varepsilon$ change in membrane thickness; $\Delta \mathrm{m}$ : Increase in membrane weight; $\mathrm{T}_{\mathrm{w}}$ : weight of water (in percentage)

\begin{tabular}{|c|c|c|c|c|c|}
\hline N117-x $-0,7$ & $\Delta \mathrm{S}(\%)$ & $\Delta \varepsilon(\%)$ & $\Delta \mathrm{m}(\%)$ & $\mathbf{T}_{\mathrm{w}}(\%)$ & R (N/S) (\%) \\
\hline 0 & & $215 \mu \mathrm{m}\left(\mathrm{t}_{0}\right)$ & & 25,4 & \\
\hline 6 & 6,2 & 12,6 & 10,4 & 35,2 & 1,47 \\
\hline 12 & 3,4 & 14,6 & 8,4 & 34,9 & 3,98 \\
\hline 48 & 3 & 13,9 & 6,4 & 32,6 & 19,48 \\
\hline \multicolumn{6}{|l|}{ N117-6-y } \\
\hline 0,07 & 4,6 & 16,2 & 15,6 & 39,3 & 0,31 \\
\hline 0,7 & 6,2 & 12,6 & 10,4 & 35,2 & 1,47 \\
\hline
\end{tabular}

*: oxidation with hydrogen peroxide. 
oxidant and $32 \%$ with only THF). The polymerization occurred in the THF-water solution on the opposite way, with hydrogen peroxide. The polymerization reaction has been carried out in the water solution.

\subsection{Characterisation by Infrared Spectroscopy}

The ATR-FTIR spectra of bulk polypyrrole and pyrrole were recorded to provide reference data (figure 4). The polypyrrole sample was prepared by oxidation with ammonium peroxodisulfate or with ferric chloride. Its ATR-FTIR spectrum presents a band characteristic of asymmetric $\mathrm{C}=\mathrm{C}$ and symmetric $\mathrm{C}-\mathrm{C}$ stretching vibrations of the pyrrole ring towards $1560 \mathrm{~cm}^{-1}$, although the exact position of the band is sensitive, via the degree of electron delocalisation, to polymer chain length, this band occurring in the pyrrole monomer at $1710 \mathrm{~cm}^{-1}$. The band at $1490 \mathrm{~cm}^{-1}$ results from ring C-N stretching vibration, and the broad absorption between 1250 and $1400 \mathrm{~cm}^{-1}$ from $\mathrm{C}-\mathrm{H}$ or $\mathrm{C}-\mathrm{N}$ in-plane deformation modes. In the region $1300-1100 \mathrm{~cm}^{-1}$, bands corresponding to the breathing vibration of the pyrrole ring are observed and $\mathrm{C}-\mathrm{H}$ and $\mathrm{N}-\mathrm{H}$ in plane deformation vibrations appear at $1050 \mathrm{~cm}^{-1}, \mathrm{C}-\mathrm{C}$ out of plane ring deformations at $974 \mathrm{~cm}^{-1}$, and bands arising from $\mathrm{C}-\mathrm{H}$ out-of-plane deformation vibrations of the pyrrole ring at 939 and $800 \mathrm{~cm}^{-1}$.

Analysis by FTIR-ATR is limited to the surface of membrane samples. The spectra given by membranes N117-T-S and N117-T-O show a similar band pattern but the intensity of absorption in the region $1300-1750$ $\mathrm{cm}^{-1}$ is different, in particular the doublet with maxima at 1725 and $1625 \mathrm{~cm}^{-1}$. Comparison of the spectra of the modified membranes with the bulk shows a shift of
$+65 \mathrm{~cm}^{-1}$ (from 1560 to $1625 \mathrm{~cm}^{-1}$ ) for the $\mathrm{C}=\mathrm{C} / \mathrm{C}-\mathrm{C}$ stretching. In an IR spectroscopic study of various (poly)pyrrole oligomers, Tian and Zerbi [21] identified $\mathrm{C}=\mathrm{C} / \mathrm{C}-\mathrm{C}$ in dipyrrole and polypyrrole at $1618 \mathrm{~cm}^{-1}$ and $1565 \mathrm{~cm}^{-1}$ respectively. This suggests that in the present case pyrrole oligomer is present on the membrane surface. Other peaks characteristic of PPy merges with the broad C-O-C absorption of Nafion ${ }^{\circledR}$ in the region at 1350 to $1100 \mathrm{~cm}^{-1}$. C-H and C-N at 1050 $\mathrm{cm}^{-1}$ and the C-C deformation at $974 \mathrm{~cm}^{-1}$ appear at the same frequencies as the intense $\mathrm{C}-\mathrm{F}$ absorption bands of Nafion ${ }^{\circledR}$ [22].

The band at $1725 \mathrm{~cm}^{-1}$ which appears in the spectra of both pyrrole-modified membranes is almost absent in the spectrum of PPy and is weakly observed in that of Nafion ${ }^{\circledR} 117$.

The spectrum of pyrrole monomer obtained by ATRFTIR has a weak absorption at $1710 \mathrm{~cm}^{-1}$ and a more intense band at $3400 \mathrm{~cm}^{-1}$ corresponding to $\mathrm{N}-\mathrm{H}$ stretching vibrations. The possibility should also be considered that Nafion ${ }^{\circledR}$ was able to concentrate monomeric pyrrole, especially with solvent (THF) as swelling agent.

The spectra of the pyrrole-modified membranes indeed show a broad band around $3300 \mathrm{~cm}^{-1}$ which is compatible with the presence of pyrrole monomer. It may thus be concluded that the absorption band at $1730 \mathrm{~cm}^{-1}$ in the pyrrole-modified Nafion ${ }^{\circledR}$ membranes is a composite band, resulting on the one hand from Nafion ${ }^{\circledR}$ and, the other from the composite membraneentrapped pyrrole.

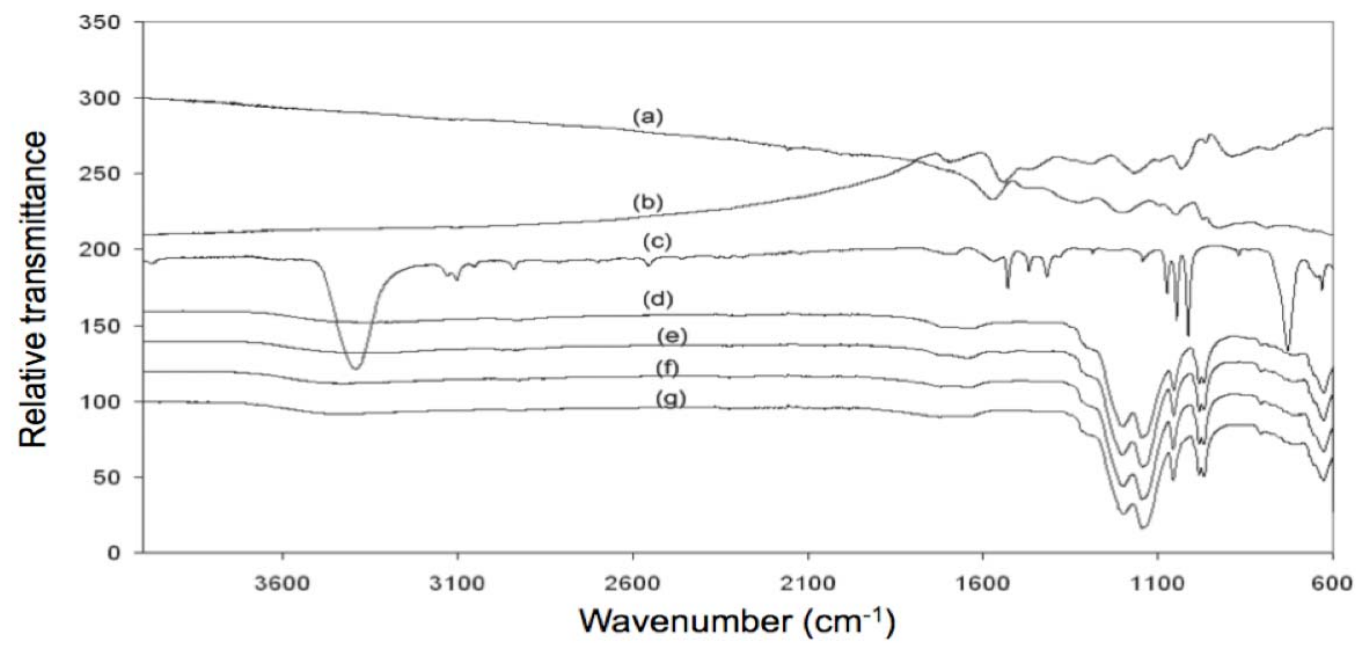

Figure 4: ATR-IRTF spectra of polypyrrole obtained by ammonium persulfate oxidation (a) ferric chloride (b) compared to pyrrole spectra (c) and membranes N117-T-24 -O (d), N117-T-48 (e), I N117-T-24 h (f) and Nafion ${ }^{\circledR} 117$ (g). 


\subsection{Ionic Conductivity of Membranes}

The electrolytes used in the conductance measurements, were $\mathrm{H}_{2} \mathrm{SO}_{4}, \mathrm{Li}_{2} \mathrm{SO}_{4}, \mathrm{Na}_{2} \mathrm{SO}_{4}$ and $\mathrm{CsSO}_{4}$, because they were soluble in water. Moreover, the use of these electrolytes allows us to investigate the cation size upon the ionic conductance, and eventually their salvation effect. We present, here, the results of the pristine membrane as well as those two modified ones namely, Nafion-THF and Nafion-THF-Fe, membranes modified during $24 \mathrm{~h}$ of polymerisation. As it can be seen on table 2, the Nafion and Nafion-THF exhibits, almost the same resistance towards the ions, except the case of the cesium ion, where an anomalous lower value was obtained with Nafion-THF. However, the Nafion-THF-Fe displays a much greater resistance towards these ions. This resistance is even higher than that of a reticulated cation exchange membrane such as $\mathrm{CMH}$. We attribute this higher resistance to the incorporated mass of polypyrrole inside the membrane during the modification, in the presence of $\mathrm{FeCl}_{3}(23 \%$ increase in weight) but only $9.9 \%$ increase in weight without $\mathrm{FeCl}_{3}$. This result seems to indicate that in the presence of both THF and $\mathrm{FeCl}_{2}$, the pyrrole polymerizes much less the hydrophobic sites and consequently, limits much less the ionic conductance inside the membrane. Furthermore, it is evident that all membranes do not present any resistance against the proton, because of its higher mobility. But with the metal cations, the resistance behaviour follows the sequence size of the solvated cations. This means, the more the cation is hydrated, the more is voluminous, and the less it penetrates into the membrane. This observation is clearly illustrated with the results of the Nafion117-THF.

\subsection{Transport Numbers of Metal Cations}

\subsubsection{Transport in Aqueous Solutions}

This study has been carried out by means of Hittorf's cells with two and three compartments separately. In effect, the transport of the monovalent cations pairs $\left(\mathrm{Li}^{+} / \mathrm{H}^{+}, \mathrm{Na}^{+} / \mathrm{H}^{+}, \mathrm{Cs}^{+} / \mathrm{H}^{+}\right.$and $\left.\mathrm{Ag}^{+} / \mathrm{H}^{+}\right)$has been done using the two compartment cell. Whilst the transport of the bivalent pairs $\left(\mathrm{Mg}^{2+}, \mathrm{Ca}^{2+} / \mathrm{H}^{+}\right.$and $\left.\mathrm{Cu}^{2+}, \mathrm{Zn}^{2+}, \mathrm{H}^{+}\right)$has been achieved using the three compartment cell, to avoid the reduction of the cation at the cathode. The Nafion ${ }^{\circledR}$ membrane was placed between the anode and central compartments, allowing the transfer of cations. The anionic AMH membrane was inserted between the central and cathode compartments, preventing the cations to pass across. For all tests, the mixed electrolyte solution of the feed compartment, contained $25 \%$ of proton and $75 \%$ of total metal cations (50\% for each metal), with an overall concentration of $0.1 \mathrm{~N}$. The concentration of acid in both central and cathode compartments was always fixed at $0.1 \mathrm{~N}$. This composition may be illustrated by the following configurations ( $\mathrm{N}$ : equiv. $\mathrm{L}^{-1}$ ).

${ }^{\text {* }}$ For binary systems

$\mathrm{H}_{2} \mathrm{SO}_{4}+\mathrm{MSO}_{4} /$ membrane $/ \mathrm{H}_{2} \mathrm{SO}_{4}$

$\begin{array}{lll}0.025 \mathrm{~N} & 0.075 \mathrm{~N} & 0.1 \mathrm{~N}\end{array}$

or

$\mathrm{HNO}+\mathrm{MNO} /$ membrane / HNO3

$\begin{array}{lll}0.025 N & 0.075 N \quad 0.1 N\end{array}$

${ }^{*}$ For ternary systems

$\mathrm{H}_{2} \mathrm{SO}_{4}+\left(50 \% \mathrm{M}_{1} \mathrm{SO}_{4}+50 \% \mathrm{M}_{2} \mathrm{SO}_{4}\right) /$ membrane $/ \mathrm{H}_{2} \mathrm{SO} 4$

$\begin{array}{lll}0.025 \mathrm{~N} & 0.075 \mathrm{~N} & 0.1 \mathrm{~N}\end{array}$

As it is shown in Figure 5, the transport numbers of the monovalent cations are almost the same and they do not differ from a membrane to another. Although, the chemical modification reduced the solvent crossover, it had not any effect on the ionic transport. The cesium having the largest ionic radius, gives the higher transport number.

Table 2: Electric resistances of both pristine and modified Nafion ${ }^{\circledR}$ membranes equilibrated with different cations

\begin{tabular}{|c|c|c|c|}
\hline Equilibrating cation & $\begin{array}{c}\text { Nafion117 } \\
\mathbf{\Omega . c m}\end{array}$ & $\begin{array}{c}\text { Nafion117-THF } \\
\mathbf{\Omega . c m}\end{array}$ & $\begin{array}{c}\text { Nafion117-THF-Fe } \\
\mathbf{\Omega . c m}^{2}\end{array}$ \\
\hline \hline $\mathrm{H}^{+}$ & 0.3 & 0.3 & 274.1 \\
\hline $\mathrm{Na}^{+}$ & 1.5 & 1.3 & 513.4 \\
\hline $\mathrm{Li}^{+}$ & 2.4 & 2.2 & - \\
\hline $\mathrm{Cs}^{+}$ & 5.7 & 0.9 & 1743.3 \\
\hline
\end{tabular}




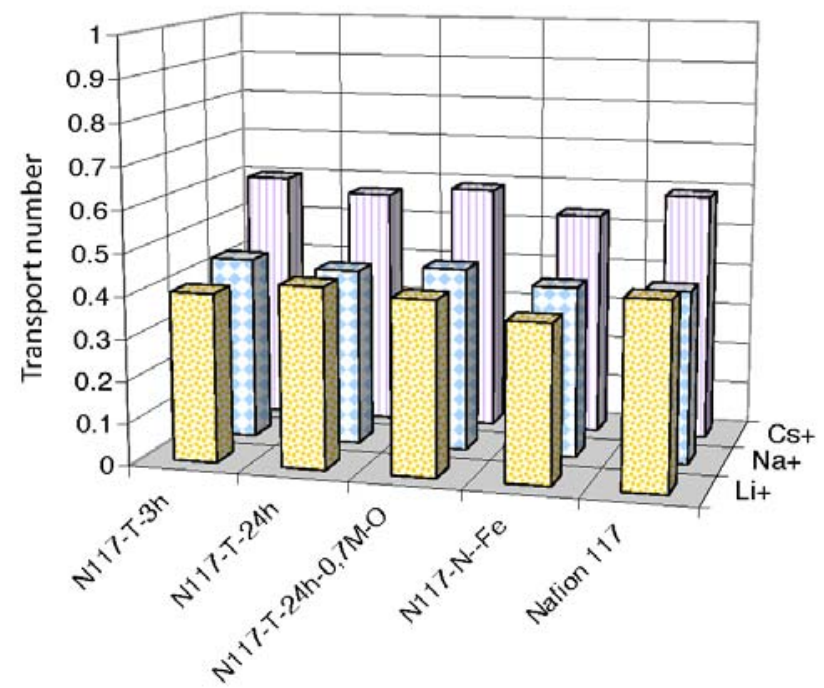

Figure 5: Transport numbers of alkali metals through modified membranes.

Furthermore, in order to estimate the competition between the proton and the metal cation, we calculated the ratios of the transport numbers $\mathrm{t}_{\mathrm{H}_{+}} / \mathrm{t}_{\mathrm{M}_{+}}$. The results presented in Figure 6 show that the membrane modified with THF as solvent and oxygenated water as oxidant, behave similarly as the pristine membrane. But with the Nafion ${ }^{\circledR}$ modified with $\mathrm{NMF}$ and $\mathrm{FeCl}_{3}$ as oxidant, the ratio was higher with the ternary system

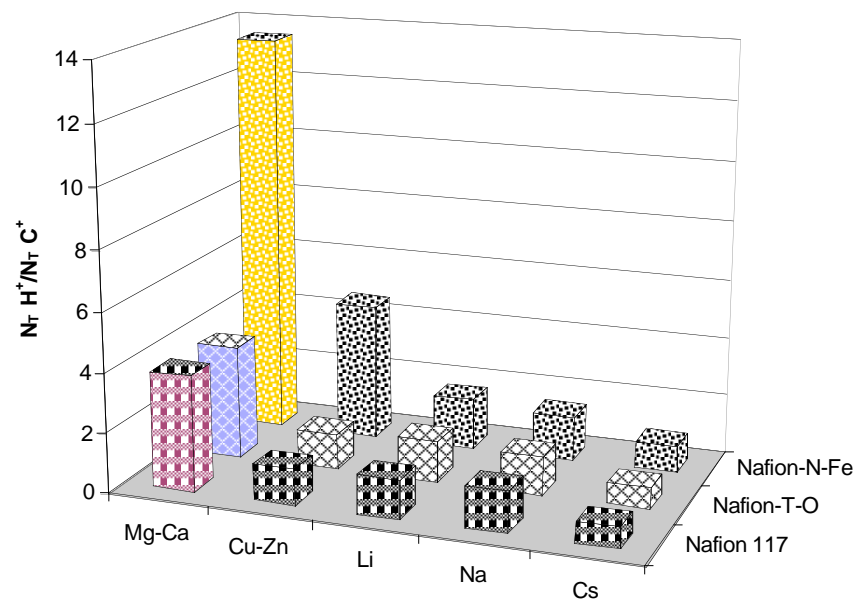

Figure 6: Transport number ratio $\left(\mathrm{N}_{\mathrm{T}} \mathrm{H}^{+} / \mathrm{N}_{\mathrm{T}} \mathrm{C}^{+}\right)$of different cations using modified membranes.

$\left(\mathrm{Cu}^{2+}, \mathrm{Zn}^{2+}, \mathrm{H}^{+}\right)$and was even higher with the system $\left(\mathrm{Mg}^{2+}, \mathrm{Ca}^{2+}, \mathrm{H}^{+}\right)$. The transport of the proton was favoured with this membrane. In contrast, the bivalent cations $\mathrm{Mg}^{2+}, \mathrm{Ca}^{2+}, \mathrm{Cu}^{2+}, \mathrm{Zn}^{2+}$ were trapped within the polymer matrix of the membrane, giving the way to the proton to pass through. The polymerisation with the oxidant $\mathrm{FeCl}_{3}$ improved the transport of the proton. For that reason, we can regard the modified membrane Nafion-N-Fe as being a good proton conductor.

\subsubsection{Transport in Mixed Solutions (Methanol- Water)}

The study of silver ion transport has been carried out in mixed solutions of methanol, using two different configurations:

Configuration (1) : binary system $\left(\mathrm{H}^{+}, \mathrm{Ag}^{+}\right)$:

$\mathrm{HNO}_{3}+\mathrm{AgNO}_{3} /$ membrane $/ \mathrm{HNO}_{3}$
$0.1 \mathrm{~N}$
$0.1 \mathrm{~N}$
$0.1 \mathrm{~N}$

Configuration (2) : ternary system $\left(\mathrm{H}^{+}, \mathrm{Na}^{+}, \mathrm{Ag}^{+}\right)$:

$\mathrm{NaNO}_{3}+\mathrm{AgNO}_{3} /$ membrane $/ \mathrm{HNO}_{3}$
$0.1 \mathrm{~N}$
$0.1 \mathrm{~N}$
$0.1 \mathrm{~N}$

${ }^{*}$ For the : binary system $\left(\mathrm{H}^{+}, \mathrm{Ag}^{+}\right)$

If we considered the experimental error, we could assume that the difference between the transport numbers of $\mathrm{Ag}^{+}$and $\mathrm{H}^{+}$, was not significant, for the non-modified membrane. However, the incorporation of sodium persulfate inside the modified membrane as oxidant, magnified this difference, by raising up the transport of the proton and falling down that of silver significantly (Figure 7). The use of $\mathrm{FeCl}_{3}$ as oxidant did not reduce the transport of silver compared to the Nafion ${ }^{\circledR}$, but increased a little bit the transport of the proton.

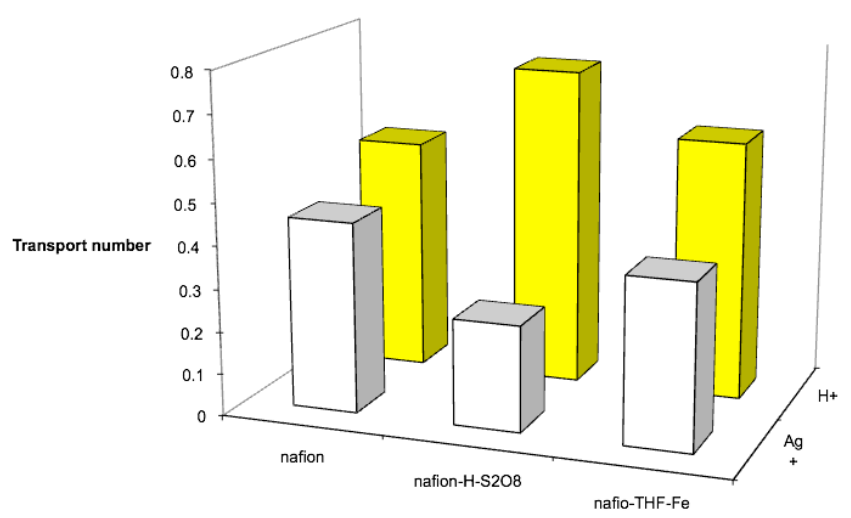

Figure 7: Transport numbers of proton and silver using modified membrane, in the presence of nitrate (binary system).

\section{${ }^{*}$ For ternary system $\left(\mathrm{H}^{+}, \mathrm{Na}^{+}, \mathrm{Ag}^{+}\right)$}

For this system, the proton was generated at the anode following a reaction of oxidation. This was made in evidence by the lower value of $\mathrm{pH}$ found at the end 
of the experiment. The results presented in Figure 8 showed that the modification of the membrane had not an effect on the transport the silver. A small decrease was observed with the sodium, when using the NafionTHF-Fe. Furthermore, as it was expected, the transport of the proton was very weak.

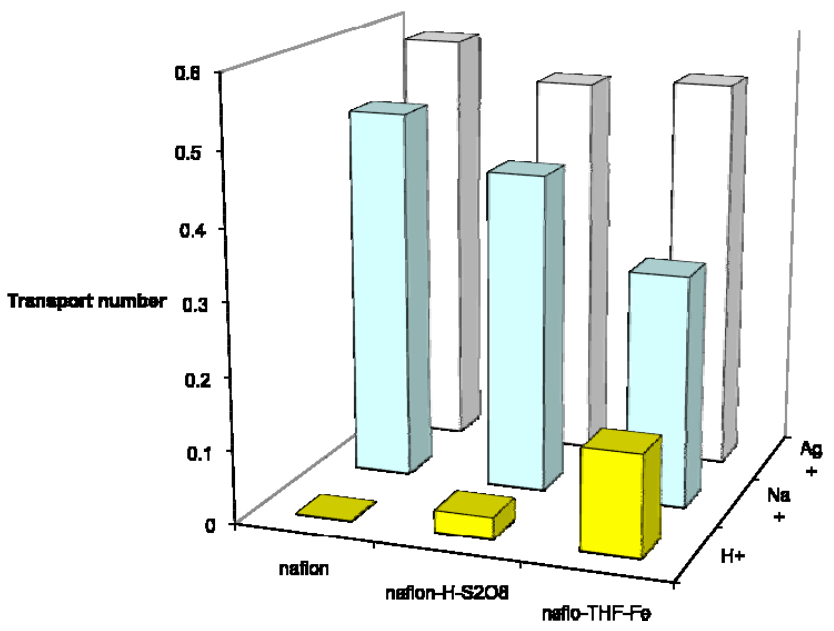

Figure 8: Transport numbers of proton, sodium and silver using modified membrane, in the presence of nitrate (ternary system).

The selectivity of the membrane towards the proton and the cations, may be determined by evaluating the ratios $t_{H_{+}} / t_{\mathrm{C}_{+}}$, using configurations 1 and 2 . The results obtained led to two hypothesises,

1). In configuration 1, the oxidant sodium persulphate enhanced the transport of the transport of the proton over that of silver. This result was expected because silver is a heavy metal, and carries less electric current when an electric field is applied.
2). In configuration 2, the presence of sodium and silver together in the solution, prevented the proton to pass through all membranes.

These results showed the influence of membrane modification on the ionic transport. The effect is significant for the proton. The presence of polypyrrole in the membrane matrix modified the proton transport because of modification of water structuring in the membrane.

\subsection{Transport of Solvent}

Table 3 illustrates the flux of methanol through both Nafion ${ }^{\circledR}$ Membrane and $\mathrm{CMH}$ membranes. Indeed, the flux of the solvent molecules is more pronounced in electro-osmosis rather than in simple diffusion, evidencing the influence of the electric field.

Besides, it is shown on this table that the modified membranes give always lower values confirming data found in the literature [23,24]. Except the case of the diffusion through the modified Nafion $117-\mathrm{H}-\mathrm{Fe}$, we find that these values obtained are close to those of the reticulated cation exchange membrane $\mathrm{CMH}$ (Neospeta ${ }^{\circledR}$ - Tokuyama Soda-Japan). Although the membrane modified in aqueous solution (i.e. Nafion $117-\mathrm{H}-\mathrm{Fe}$ ), is the least permeable to methanol, it presents unfortunately the highest resistance value. For this reason, we ignored it in our study. Thus, the membrane modified in $\mathrm{N}$-methlformamide (i.e. Nafion117-N-Fe) is the good candidate for the purpose of our study. It allows less methanol to pass through and avoids the saturation of its exchange sites.

\section{CONCLUSION}

In both diffusion and electro-osmosis, it is possible

Table 3. Flux of Methanol Through both the Nafion ${ }^{\circledR}$ Membrane and corresponding Modified Membranes Nafion117-NFe; Nafion117-H-Fe

\begin{tabular}{|c|c|c|}
\hline Type of Membrane & $\begin{array}{c}\text { Flux } \\
\underset{\text { Diffusion }}{\left(m m^{-1} \cdot \mathrm{cm}^{-2}\right)}\end{array}$ & 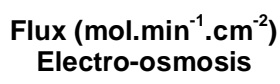 \\
\hline $\begin{array}{l}8 \% \text { methanol } \\
\text { Nafion117 }\end{array}$ & $3.40 \times 10^{-6}$ & $7.33 \times 10^{-6}$ \\
\hline $\begin{array}{l}50 \% \text { methanol } \\
\text { Nafion117 }\end{array}$ & $32.5 \times 10^{-6}$ & $57.5 \times 10^{-6}$ \\
\hline $\begin{array}{l}50 \% \text { methanol } \\
\text { Nafion117-N-Fe }\end{array}$ & $6.79 \times 10^{-6}$ & $13.7 \times 10^{-6}$ \\
\hline $\begin{array}{l}50 \% \text { methanol } \\
\text { Nafion117-H-Fe }\end{array}$ & $0.21 \times 10^{-6}$ & $7.37 \times 10^{-6}$ \\
\hline $\begin{array}{l}50 \% \text { methanol } \\
\mathrm{CMH}\end{array}$ & $\underline{4.97 \times 10^{-6}}$ & $\underline{4.68 \times 10^{-6}}$ \\
\hline
\end{tabular}


to reduce the permeability of the Nafion ${ }^{\circledR}$ membrane against methanol, by modifying it chemically with polypyrrole. However, this latter increases considerably the transport of metal cations. Thence, the modified membrane may be regarded as a good metal conductor and bad solvent transporter. Therefore, it may be used successfully in electrodialysis of electrolyte solutions in hydro-organic media.

\section{REFERENCES}

[1] Easton EB, Langsdorf BL, Hughes JA, Sultan J, Qi Z, Kaufman A, Pickup PG. J Electrochem Soc 2003; 150: C735C739. http://dx.doi.org/10.1149/1.1608005

[2] Langsdorf BL, Maclean BJ, Halfyard JE, Hughes JA, Pickup PG. J Phys Chem B 2003; 107: 2480-2484. http://dx.doi.org/10.1021/jp026840c

[3] Alberti G, Casciola M. Annu Rev Mater Res 2003; 33: 129_ 154.

http://dx.doi.org/10.1146/annurev.matsci.33.022702.154702

[4] Chang CM., Huang HJ. Anal Chim Acta 1995; 300: 15-23. http://dx.doi.org/10.1016/0003-2670(94)00379-Z

[5] Partridge AC, Milestone CB, Too CO, Wallace GG. J Memb Sci 1999; 152: 61. http://dx.doi.org/10.1016/S0376-7388(98)00193-8

[6] Ariza MJ, Otero TF. Colloids Surf. A: Physicochem. Eng. Aspects 2005; 226: 270-271

[7] Zachara JE, Toczyłowska R, Pokrop R, Zagorska M, Dybko A, Wroblewski W. Sens. Actuators B 2004; 101: 207-212. http://dx.doi.org/10.1016/..snb.2004.02.052

[8] Wang L-X, Li X-G., Yang Y-L. React Funct Polym 2001; 47: 125-139.

http://dx.doi.org/10.1016/S1381-5148(00)00079-1

[9] Burgmayer P, Murray RW. J Am Chem Soc 1982; 104: 61396140.

http://dx.doi.org/10.1021/ja00386a061
[10] Partridge AC, Milestone C, Too CO, Wallace GG. J Memb Sci 1997; 132: 245

http://dx.doi.org/10.1016/S0376-7388(97)00072-0

[11] Zhao H, Price WE, Wallace GG. Polymer 1993; 34: 16-20. http://dx.doi.org/10.1016/0032-3861(93)90276-G

[12] Sata T, Ogura S, Kiskimoto F. J Memb Sci 1993; 84: 259269. http://dx.doi.org/10.1016/0376-7388(93)80021-O

[13] Xu F, Innocent C, Bonnet B, Jones DJ, Rosiere J. Fuel Cells 2005; 5: 398-405 http://dx.doi.org/10.1002/fuce. 200400077

[14] Kameche M, Xu F, Innocent C, Pourcelly G, Derriche Z. Desalination 2004; 168: 319-327. http://dx.doi.org/10.1016/j.desal.2004.07.015

[15] Kameche M, Xu F, Innocent C, Pourcelly G. Desalination 2003; 153: 9-15. http://dx.doi.org/10.1016/S0011-9164(03)00203-0

[16] Innocent C, Huguet P, Kameche M, Bribes JL, Pourcelly G. Phys Chem Chem Phys 2001; 3: 1481-1485. http://dx.doi.org/10.1039/b008318f

[17] Kameche M, Innocent C, Xu F, Pourcelly G, Derriche Z. Desalination 2004; 168: 319-327. http://dx.doi.org/10.1016/j.desal.2004.07.015

[18] Xu F, Innocent C, Pourcelly G. Sep Pur Technol 2005; 43 : 17-24. http://dx.doi.org/10.1016/j.seppur.2004.09.009

[19] Chaabane L, Innocent C, Bulvestre G, Pourcelly G, Auclair B. Eur Polym J 2006; 42: 14036-1416. http://dx.doi.org/10.1016/j.eurpolymj.2005.12.019

[20] Tian B, Zerbi G. J Chem Phys 1990; 92: 3892-3898 http://dx.doi.org/10.1063/1.457795

[21] Hong L, Zhou Y, Chen N, Li K. J Colloid Interface Sci 1999; 218: 233-242 http://dx.doi.org/10.1006/jcis.1999.6385

[22] Jia N, Lefebvre MC, Hafyrad J, Qi Z, Pickup PG. Electrochem Solid State Letter, 2000;3: 529-531. http://dx.doi.org/10.1149/1.1391199

[23] Sungpet A. J Memb Sci 2003; 226: 131-134. http://dx.doi.org/10.1016/j.memsci.2003.08.015

Received on 20-09-2012

Accepted on 08-12-2012

Published on 31-12-2012

DOI: http://dx.doi.org/10.6000/1929-6037.2012.01.02.5

(c) 2012 Xu et al.; Licensee Lifescience Global.

This is an open access article licensed under the terms of the Creative Commons Attribution Non-Commercial License (http://creativecommons.org/licenses/by-nc/3.0/) which permits unrestricted, non-commercial use, distribution and reproduction in any medium, provided the work is properly cited. 